\title{
An analysis of the length of labour and financial contracts: a study $\equiv$ for Spain
}

\author{
Josep A. Tribó \\ Department of Business Administration, Universidad Carlos III, C/ Madrid \\ 126, Getafe 28903, Spain \\ E-mail: joatribo@emp.uc3m.es
}

This study investigates the connection between the duration of financial contracts and that of labour contracts. Workers with long-term contracts have incentives to invest in training. This makes them attractive to the entrepreneur. Furthermore, this behaviour will be reinforced if financial contracts are long-term, because it reduces the probability of an early liquidation as well as the dismissal of trained workers. As a conclusion, significant increases in the length of financing contracts should be accompanied by corresponding increases in the length of labour contracts. Support for this theoretical contention is found by testing it on a dataset composed of Spanish manufacturing firms for the period 1991-2000.

\section{Introduction}

A firm's efficiency is very much related to its ability to manage optimality its resources (intangible, financial, and physical) that are obtained through different types of contracts (labour and financial among others). To achieve this aim, a firm tries to coordinate these resources closely by complementing the characteristics of the contracts that govern their supply. This study focuses on the length of contracts and the scope is restricted to financial and labour contracting. Labour contracts are those through which workers provide human capital to firms, while financial contracts give firms access to financial resources. Our conjecture is that the length of both contracts is closely related, and variations in the length of one contract are translated into variations in the length of the other.

Traditionally, there is a trade-off to find the optimal length for labour contracts. This is so as to balance the cost of negotiating different short-term contracts with the lack of flexibility of long-term contracts in an uncertain environment (Gray, 1978; Dye, 1985). The higher the uncertainty, the more attractive are short-term contracts (Murphy, 2000). Within this setting, there are different factors that play a role in the previous balance. First, the commitment effect linked to long-term labour contracts favours a firm's specific investments like those that accompany long-term labour contracting. Second, the shortsightnesss of shareholders may induce managers to adopt short-term investment policies. Third, the lack of flexibility of long-term labour contracts acts like a 'poison pill' to deter potential raiders (Pagano and Volpin, 2002). However, these contracts generally involve superior investment levels as well as lower levels of disposable cash flow for managers, which in turn, improve a firm's value (Del Brio et al., 2003). This would make these firms with long-term labour contracts more attractive as take over targets. Lastly, the presence of intermediaries such as unions may favour short-term contracts as a way of maintaining their bargaining power within the firm (Hendricks and Kahn, 1983; Murphy, 1992) or long-term contracts (Bárcena and Campo, 2000). Also, Ayala et al. (2002), making use of a sample of OECD countries, finds that collective bargaining co-ordination, which is more feasible in the presence 
of unions, reduces the unemployment rate and with that the replacement rate. This makes labour contracts more long-term in their nature. This factor is important in Spain because, as the former authors show, collective bargaining covers $68 \%$ of the Spanish labour force.

Interestingly, a firms financing resources affect the previous balance of factors. Long-term capital represents a financier's commitment that allows the firm more flexibility in facing uncertainty. In addition, the greater the financier's commitment, the more willing a firm is to make specific investment (i.e. in human capital). Consequently, workers with long-term contracts are more attractive. Thus, it seems natural that variations in a characteristic of financial contracts, like their length, should have and impact on the length of labour contracts.

This is not the first study to examine the interactions between labour and financial relationships. Some authors have already studied both contracts jointly although addressing a different question to ours. Garvey and Swan (1992), shows that debtfinanced firms' workers are more cooperative than those from equity-financed firms. Osano (1997) proves, using an evolutive model, that a financial contract that prevents the liquidation of a project at an early stage of development (long-term debt), is more efficient when complemented with a labour contract that motivates workers to make some efforts. Tsouhoulas (1999) shows that debt contracts can only survive when workers can commit in advance not to renegotiate their labour contracts with the firm, (i.e. workers with few options outside those who are hired with short-term labour contracts). Along these lines, Hanka (1998) makes an empirical study for the USA and concludes that: the more indebted a firm, the more disciplined are its workers, and the higher its proportion of temporal workers. Finally, Martin (2003) confirms indirectly Hanka result by showing the diminishing commitment value of firm's specific capital in presence of debt. Although he focuses on physical capital, the extension to specific human capital (more linked to long-term workers) in the presence of debt is straightforward.

This study goes a step further than Hanka, as it distinguishes between long-term debt and short-term debt. This is relevant because this will allow one to focus on what is thought to be the real financing determinant of labour contract length - the financial contract length.

The first objective in this study is to present a theoretical framework that it is formally developed in Hernando and Tribó (2003) to justify the linkage between the length of labour contracts and financial contacts. The basic idea is that extended contract length stimulates specific investments. Workers with long-term contracts have incentives to increase their human capital by making specific investments in training (Becker, 1964). Moreover, this behaviour will be reinforced when these workers perceive that financiers are committed to the firm. A natural indicator for this financier commitment is the length of financial contracts, because it reduces the probability of an early liquidation. Furthermore, workers by making these efforts make financiers' returns more likely and, lenders will stimulate this process by providing long-term capital, which makes long-term labour contracts even more attractive. As a conclusion, significant increases in the length of financing contracts should be accompanied by similar increases in the length of labour contracts. This is in line with Ragan (1995), although he introduces risk considerations to obtain a positive relationship between firms' bargaining power (higher for highlength financial contracts), and the length of labour contracts.

The second objective of this study is to conduct an empirical analysis to test the main theoretical findings on a data set composed of Spanish manufacturing firms for the period 1991-2000. This is a quite relevant period, as an important reform to stimulate long-term labour contracting was implemented in 1997. Evidence is found that those firms that have increased (decreased) significantly their financial contract length, have also increased (decreased) their labour contract length. Furthermore, it is also observed that labour contract length is directly related to the level of a firm's $R \& D$ investments as well as to its degree of diversification. In addition, it is inversely related to increases in financing costs. This latter result coincides with Rendón (2000) that shows, using a database of Spanish manufacturing firms that financially constrained firms hire more temporary workers than permanent ones.

This article is organized as follows. Section II presents the theoretical underpinnings. The methodology to estimate is explained in Section III, and the results are presented in Section IV. The article concludes in Section V with some final remarks.

\section{Theoretical Underpinnings}

The main argument of the paper can be shown with a very simple model. ${ }^{1} \mathrm{~A}$ firm undertakes a project that

\footnotetext{
${ }^{1}$ This model is formally developed in Hernando and Tribó (2003).
} 
lasts for two periods and seeks some financing. Once the capital has been found, the firm has the possibility of hiring workers offering them two types of contracts: a short-term contract (one-period contract) or a long-term contract (two-period contract). Workers have the possibility to implement nonverifiable effort, $e$, in the first period, which is firm specific, in order to become more productive in the second period. This will generate some additional returns that are tangible, thus, allowing compensating the workers for that effort, $e$, produced in the previous period. The point is that only workers with a two-period contract (long-term contract) will have incentives to implement this effort, $e$. Short-term workers, since they have no assurance of being employed in the second period, do not make any effort. ${ }^{2}$ The intensity of this effort will be much dependent on the probability of project liquidation, $P$, at the end of the first period. The higher the $P$, the lower workers' willingness will be to implement effort $e$, because after project liquidation there is no compensation for first-period effort. The point is that this probability $P$ relies on, among other things, the length of financial contracts that tie a firm to its lenders. ${ }^{3}$ In addition, the higher this length, the lower the $P$ will be and, consequently, the higher the workers' incentives for effort $e$. Thus, within this long-term financial contract scenario, the entrepreneur will prefer to hire workers with long-term contracts and exploit workers' willingness to make effort $e .^{4}$ Moreover, by implementing this effort, the payment to lenders is more likely and they will, in turn, reinforce that workers' behaviour by accepting longterm lending to finance the initial project. ${ }^{5}$ The outcome is a complementarity relationship between the length of labour contracts and of financial contracts.

According to this simple model, it is expected that borrowing significant new funds through long-term (short-term) financial contracts should be accompanied by recruiting a significantly higher proportion of workers with long-term (short-term) labour contracts. This is the main hypothesis to contrast.

Under the resource-based view of the firm that is adopted, the financing effect described above related to the optimal definition of labour contract length, competes with the effects of other resources of the firm. In particular, and following (Wernerfelt, 1984; Barney, 1991), one can mention:

- Financing resources: Cost of debt is inversely related to lenders' commitment to a firm. Its reduction, according to the aforementioned arguments, should promote long-term labour contracting by stimulating human capital investment. In addition, the higher the cost of debt, the more likely the entrepreneur is to hire workers with a short-term contract because their costs are lower in real terms (Sánchez and Toharia, 2000).

- Physical resources: Project type. It is understood that for high-quality projects (especially if they are long-term), increases in workers' productivity as a result of human capital investment generate more returns than for low-quality ones. This will also promote long-term labour contracting.

- Human Capital resources: Workers' productivity. Those workers with the potential to increase substantially their productivity with a specific training effort will give entrepreneurs incentives to offer them long-length contracts. Becker (1964) shows that long tenure is associated with productivity-enhancing specific human capital. It is argued that this should be especially true in those firms that invest intensively in $R \& D$, as that kind of investment improves the returns from human capital investment. Llorca (2002) finds, using a sample of Spanish firms, a very significant positive relationship between $R \& D$ investment and worker's productivity, especially when this investment is in process innovation.

To synthesize, it can be stated that an entrepreneur's willingness to hire long-term workers is greater given three scenarios.

- First, when the lender's commitment to the firm is high (long-term and/or low-cost lending);

- Second, when projects are high quality and long-term. Generally, R\&D-intensive projects satisfy these conditions;

- Finally, when workers' productivity is high.

\footnotetext{
${ }^{2}$ An alternative approach would have been to introduce the possibility to extend short-term workers' contracts if their efforts, $e$, are high enough. The problem is that this arrangement is contingent on $e$, which is not verifiable and only produces some tangible results at the end of the second period.

${ }^{3}$ Questions of renegotiation can be ruled out at this point.

${ }^{4}$ Topel (1986) describes a long-term contract as a bond between the worker and the firm. This gives log-term workers incentives to implement specific human capital investment.

${ }^{5}$ The firm is competing in a perfect competitive market and it is a contract taker.
} 


\section{Methodology}

A firm's variation in its labour contract length is estimated by considering a set of its internal resources as well as some other factors. The temporal labour ratio (defined as the ratio of temporal workers to total workers) is used as a proxy inversely related to a firm's labour contract length. From the previous arguments (a new project financing scenario where a firm hires workers), those situations are highlighted with a significant variation in that ratio. There are two possibilities: Firms that hire the majority of workers with short-term contracts (raises the temporal labour ratio), and others that make use of long-term contracts (decreases the temporal labour ratio). Each alternative is characterized with two different variables. ILR is a dummy variable, which is equal to one when two conditions are met. First, there is an increase in the temporal labour ratio, which is higher than the median for the sector in that year. Second, there is an increase in the number of workers. The alternative variable, RILR (relative increase in the labour ratio), is the continuous version of ILR. Its value is zero when ILR $=0$, and it is the difference between the variation of a firm's labour ratio and the variation of that ratio for the corresponding sector in that year, when ILR $=1$. This variable gives a more accurate measure of the relevant increases in the length of a firm's labour contracts.

For the decrease in the labour ratio, two alternative variables are considered. DELR is a dummy variable that is equal to one, when two other conditions are met. First, there is a decrease in the temporal labour ratio higher than the median for the sector in that year. Second, there is an increase in the number of workers. The other variable, RDELR, is defined in terms of DELR. Its value is zero when DELR $=0$. It is the absolute value of the difference between the variation of a firm's labour ratio and the variation of that ratio for the corresponding sector in that year, when $\operatorname{DELR}=1$. This ensures a positive-definite variable that makes the interpretation of the results easier.

These variables are introduced advanced by one period. This is to prevent possible endogeneity problems with independent variables such as those that characterize a firm's productivity (see below).

To explain dummy variables, ILR and DLR, one has to rely on logit estimations (Maddala, 1983). In addition, for continuous but truncated variables, RILR and RDELR, Tobit estimations are focused on (Greene, 1993).

The basic specification takes into consideration as main variables those that measure variations in the length of financial contract. Additionally, the study introduces as control variables the set of resources that define a firm (Wernerfelt, 1984; Barney, 1991) as well as other factors that are traditionally considered to study the length of labour contracts. These are firm's size, uncertainty and risks. In particular, the set of explanatory variables can be grouped in the following way.

\section{Main variables}

There are two basic variables to test the main hypothesis of the paper. Dummy variable IFR, is equal to one when two conditions are met. First, there is an increase in the debt-financing ratio (short-term debt to total debt) higher than the median for the sector in that year. Second, there is an increase in the total debt. Alternatively, DEFR is a dummy variable that it is equal to one when these conditions are met. First, there is a decrease in the financing ratio higher than the median for the sector in that year. Second, there is an increase in the firm's debt. The idea is to highlight those situations where a firm is engaged in project financing (there is an increase in the total debt) and there is a significant change in the length of a firm's debt.

In those estimations using RILR and RDELR as continuous dependent variables, one considers as main variables those equivalents constructed with the financing ratio. RIFR is zero when $\operatorname{IFR}=0$, and it is the difference between the variation of a firms financing ratio and the variation of the median value of that ratio in the corresponding sector in that year, when IFR $=1$. However, RDEFR is defined in terms of DEFR. Its value is zero when DEFR $=0$. It is the absolute value of the difference between the variation of a firm's financing ratio and the variation of the median value of that ratio in the corresponding sector in that year, when DEFR $=1$. RIFR and RDEFR variables show the magnitude of the variation of a firm's financing ratio compared with their counterparts in the same sector and for a given year.

In order not to introduce asymmetries with dependent variables, these variables are also advanced by one period. This may generate additional endogeneity problems that are going to be treated in a specific section below.

Consistent with the previous arguments in the theoretical section, the previous variables are used to focus on those situations where a firm undertakes a project relevant enough to modify the 'average length' of its outstanding contracts. This factor would be reflected as a significant change in a firm's commitments (financial as well as labour). That is, one only expects to find a linkage between a firm's financing and labour structure in those situations involving relevant changes in both variables. 
In order to isolate the specific effect of variations in the length of financial contracts from other effects linked to other resources of the firm, the following Control Variables are proposed.

\section{Tangible resources (financing and physical)}

DIFINCOST is the change in the firm's bank financing costs. This important variable reflects different factors. First, it is a measure of a lender's commitment to a firm. A logical way to back the firm's activities is to ask for lower returns in exchange for the capital lent. A second feature that reflects this variable is project quality, the higher the quality, the lower the cost of capital. Finally, uncertainty and risk, in general, also increases the value of this variable. Taking into account the above factors, one expects a negative relationship between this variable and increases in labour contract length.

To complement the previous variable, one uses LTBANKDEBT, which is the ratio of long-term bank debt to total bank debt. This is an alternative measure of the financier's commitment with the firm (Sharpe, 1990). In addition, firms with such a financial structure can afford long-term projects.

Finally, the variable LEVERAGE has also been introduced, defined as the ratio of a firm's debt to internal funds. This variable will allow one to check Hanka's (1998) result for the relationship between leverage and the hiring of temporal workers.

\section{Intangible resources}

A variable that accounts for workers' productivity (PRODUCTIVITY) is defined as a firm's production to the total number of workers.

$\mathrm{RD}$ is the ratio of $\mathrm{R} \& \mathrm{D}$ expenses to sales. This is the classical measure of investment in intangibles. In addition, this variable reflects the future expectations of a firm's returns. This will allow one to test whether the relationship between labour and financial contract length is spurious. That is, whether the underlying cause that links both lengths is the magnitude of these expectations: The higher (lower) these expectations, the higher (lower) the length of both contracts.

\section{Additional controls}

SMALL is a dummy variable that it is equal to $1(0)$ if the firm has less (more) than 50 employees. This variable controls for size effects. Along these lines, Sharpe (1994) finds that changes in the workforce along the cycle depend on a firm's size.
DIVERSIFIC. This variable is defined as $\sqrt{\sum_{1=1}^{N} S_{i}^{2}}$ where $S_{i}$ is a firm's percentage of its sales in market $i$. The more diversified a firm, the lower the value of this variable. In addition, this variable can be connected with a firm's risk.

Thus, the logit specification we consider once dependent variables ILR and DELR are used is as follows:

$$
\begin{aligned}
& \left\{\begin{array}{l}
\mathrm{T}(\mathrm{ILR}) \\
\mathrm{T}(\mathrm{DELR})
\end{array}\right\}_{i t} \\
& =\alpha_{1} \mathrm{IFR}_{i t}+\alpha_{2} \mathrm{DEFR}_{i t}+\alpha_{3} \text { DIFINCOST }_{i t} \\
& +\alpha_{4} \text { LTBANKDEBT }_{i t}+\alpha_{5} \text { LEVERAGE }_{i t} \\
& +\alpha_{6} \text { PRODUCTIVITY }_{i t}+\alpha_{7} \mathrm{RD}_{i t} \\
& +\alpha_{8} \text { SMALL }_{i t}+\alpha_{9} \text { DIVERSIFIC }_{\cdot i t}+\left\{\begin{array}{l}
\eta_{i}+\varepsilon_{i t} \\
\eta_{i}^{\prime}+\varepsilon_{i t}^{\prime}
\end{array}\right\}
\end{aligned}
$$

Where, $\quad \mathrm{T}(\mathrm{ILR})=\log (\operatorname{prob}(\mathrm{ILR}=1) / 1-$ prob $(I L R=1))$ and $\mathrm{T}(\mathrm{DELR})=\log (\operatorname{prob}(\mathrm{DELR}=1) /$ $1-\operatorname{prob}(\mathrm{DELR}=1)) \eta_{i}, \eta_{i}^{\prime}$ accounts for the unobservable heterogeneity, and $\varepsilon_{i}, \varepsilon_{i}^{\prime}$ are white-noise error terms.

Initially, both equations are estimated separately (see Table 1). Then, one recognizes the possibility of a joint determination of financing and labour ratio (see below).

In addition, as aforementioned, Tobit estimations (Green, 1993, p. 697) are conducted with dependent variables RILR and RDELR. ${ }^{6}$ In this case, the latent dependent variables follow this observability rule:

$$
\begin{aligned}
& \mathrm{RILR}_{i t}^{*}=\left\{\begin{array}{c}
\mathrm{RILR}_{i t} \equiv \mathrm{VLR}_{i t}-\operatorname{MEDIAN}_{t}(\mathrm{VLR}) \\
\text { if } \mathrm{RILR}_{i t}>0 \Leftrightarrow \mathrm{ILR}_{i t}=1 \\
0 \quad \text { Otherwise }
\end{array}\right\} \\
& \operatorname{RDELR}_{i t}^{*}=\left\{\begin{array}{l}
\operatorname{MEDIAN}_{t}(\mathrm{VLR})-\mathrm{VLR}_{i t} \\
\text { if } \operatorname{RDELR}_{i t}>0 \Leftrightarrow \operatorname{DELR}_{i t}=1 \\
0 \quad \text { Otherwise }
\end{array}\right\}
\end{aligned}
$$

where VLR is the variation between period $t+1$ and period $t$ of the labour ratio as it has been defined. The median value of that ratio is taken with respect to sector and year.

Note that both variables are not complementary because of the condition $\mathrm{ILR}_{i t}=0 \neq \mathrm{DELR}_{i t}=1$.

By construction, the importance of a firm's resources is recognized in explaining the definition of its labour contracts length. However, one only considers a set of these resources in the estimations. This implies that those, which are not explicit in the

${ }^{6} \mathrm{By}$ construction, half of the observations have a zero value for these variables. 
Table 1. Univariate estimations

\begin{tabular}{|c|c|c|c|c|c|c|}
\hline & $\operatorname{DELR}^{\mathrm{a}, \mathrm{b}}$ & $\operatorname{RDELR}^{\mathrm{a}, \mathrm{c}}$ & $\operatorname{RDELR}^{\mathrm{a}, \mathrm{c}}$ & $\operatorname{ILR}^{\mathrm{a}, \mathrm{b}}$ & $\operatorname{RILR}^{\mathrm{a}, \mathrm{c}}$ & RILR $^{\mathrm{a}, \mathrm{c}}$ \\
\hline DEFR & $\begin{array}{l}0.301 * * * \\
(3.000)\end{array}$ & & & $\begin{array}{l}0.326^{* * *} \\
(3.97)\end{array}$ & & \\
\hline IFR & $\begin{array}{c}0.090 \\
(0.980)\end{array}$ & & & $\begin{array}{l}0.357^{* * * *} \\
(4.75)\end{array}$ & & \\
\hline RDEFR & & $\begin{array}{l}0.081 * * * \\
(2.58)\end{array}$ & $\begin{array}{c}0.025 \\
(0.61)\end{array}$ & & $\begin{array}{c}0.034 \\
(0.028)\end{array}$ & $\begin{array}{c}0.027 \\
(0.76)\end{array}$ \\
\hline RIFR & & $\begin{array}{l}-0.034 \\
(-1.04)\end{array}$ & $\begin{array}{l}-0.108^{* *} \\
(2.67)\end{array}$ & & $\begin{array}{l}0.079^{* * *} \\
(0.026)\end{array}$ & $\begin{array}{l}0.095^{* * *} \\
(3.42)\end{array}$ \\
\hline D97RDEFR & & & $\begin{array}{l}0.140^{* * * *} \\
(2.35)\end{array}$ & & & $\begin{array}{c}0.014 \\
(0.27)\end{array}$ \\
\hline D97RIFR & & & $\begin{array}{l}0.277^{* * *} \\
(4.13)\end{array}$ & & & $\begin{array}{l}-0.089 \\
(-1.53)\end{array}$ \\
\hline DIFINCOSTS & $\begin{array}{r}0.018^{*} \\
(-1.660)\end{array}$ & $\begin{array}{l}-0.001 * * \\
(-1.77)\end{array}$ & $\begin{array}{l}-0.001^{*} \\
(-1.58)\end{array}$ & $\begin{array}{l}-0.003 \\
(-0.38)\end{array}$ & $\begin{array}{l}-0 \\
(-0.058)\end{array}$ & $\begin{array}{l}-0 \\
(-0.62)\end{array}$ \\
\hline LTBANKDEBT & $\begin{array}{c}0.135 \\
(0.800)\end{array}$ & $\begin{array}{l}0.032^{* * *} \\
(3.85)\end{array}$ & $\begin{array}{l}0.031^{* * *} \\
(3.66)\end{array}$ & $\begin{array}{r}0.082 \\
(0.61)\end{array}$ & $\begin{array}{c}0.004 \\
(0.62)\end{array}$ & $\begin{array}{r}0.005 \\
(0.73)\end{array}$ \\
\hline LEVERAGE × 100 & $\begin{array}{c}-0.145 \\
(-0.750)\end{array}$ & $\begin{array}{l}-0.005 \\
(-0.39)\end{array}$ & $\begin{array}{l}-0.005 \\
(-0.35)\end{array}$ & $\begin{array}{c}0.054 \\
(0.31)\end{array}$ & $\begin{array}{l}-0.010 \\
(-0.86)\end{array}$ & $\begin{array}{l}-0.010 \\
(-0.86)\end{array}$ \\
\hline PRODUCTIVITY & $\begin{array}{c}0 * * * \\
(4.630)\end{array}$ & $\begin{array}{l}0 \\
(1.30)\end{array}$ & $\begin{array}{l}0 \\
(1.28)\end{array}$ & $\begin{array}{r}0 * * * \\
(6.48)\end{array}$ & $\begin{array}{r}0^{* * * *} \\
(2.83)\end{array}$ & $\begin{array}{r}0^{* * *} \\
(2.85)\end{array}$ \\
\hline $\mathrm{RD}$ & $\begin{array}{c}0.305 \\
(1.050)\end{array}$ & $\begin{array}{l}0.209^{*} \\
(1.73)\end{array}$ & $\begin{array}{l}0.217 * * \\
(1.80)\end{array}$ & $\begin{array}{l}1.253 \\
(0.56)\end{array}$ & $\begin{array}{c}0.052 \\
(0.48)\end{array}$ & $\begin{array}{r}0.054 \\
(0.49)\end{array}$ \\
\hline SMALL & $\begin{array}{c}0.146 \\
(0.55)\end{array}$ & $\begin{array}{l}0.006 \\
(1.00)\end{array}$ & $\begin{array}{c}0.006 \\
(0.620)\end{array}$ & $\begin{array}{l}1.149^{* * * *} \\
(4.31)\end{array}$ & $\begin{array}{l}0.006 \\
(1.11)\end{array}$ & $\begin{array}{l}0.006 \\
(1.10)\end{array}$ \\
\hline DIVERSIFIC. & $\begin{array}{l}0.009^{* * *} \\
(2.210)\end{array}$ & $\begin{array}{c}0.000 \\
(1.42)\end{array}$ & $\begin{array}{r}0.009 \\
(1.42)\end{array}$ & $\begin{array}{r}0.004 \\
(1.27)\end{array}$ & $\begin{array}{c}0.004 \\
(1.190)\end{array}$ & $\begin{array}{l}0 \\
(0.57)\end{array}$ \\
\hline Number observ. & 3658 & 7163 & 7163 & 5178 & 7163 & 7163 \\
\hline Log likelihood & -1343.954 & -1447.217 & -1436.014 & -2027.102 & -1514.557 & -1513.33 \\
\hline LR ratio test & $\begin{array}{l}44.75 \\
(0)\end{array}$ & $\begin{array}{l}35.29 \\
(0)\end{array}$ & $\begin{array}{l}57.70 \\
(0)\end{array}$ & $\begin{array}{l}107.60 \\
(0)\end{array}$ & $\begin{array}{l}23.45 \\
(0.008)\end{array}$ & $\begin{array}{l}25.89 \\
(0.008)\end{array}$ \\
\hline
\end{tabular}

a***1\% significant; **5\% significant; $* 10 \%$ significant. $P$-values in parentheses. Variables defined in the text.

${ }^{\mathrm{b}}$ Conditional logit estimations.

${ }^{\mathrm{c}}$ Tobit estimations.

variables used, are implicit under the unobservable heterogeneity $\left(\eta_{i}\right)$. The complementarity between different firms resources imply that $\eta_{i}$ is expected to correlate with the aforementioned explanatory variables (fixed effects). Thus, one has to take advantage of the conditional logit (Chamberlain, 1980) in the estimation of ILR and DELR in order to eliminate this unobservable heterogeneity and find consistent estimators. The basic idea is to condition the maximum likelihood function on the sum of the different realizations of the dependent variable for each individual (Greene, 1993, p. 656). The shortcoming of using logit estimations is that one has to rely on dummy variables to measure changes in the length of contracts. That is why Tobit estimations have been conducted on variables RIFR and
RDEFR. However, these estimations do not control for the potential endogeneity problem of the unobservable heterogeneity. ${ }^{7}$

Once the previous estimations have been conducted, one moves a step further to deal with the problem of potential endogeneity between the definition of the length of financial contracts and of labour contracts. This is precisely what has been argued in the theoretical section. A standard way to deal with this problem is by instrumenting the independent variables making use of temporal lags. ${ }^{8}$ However, this strategy does not work well either for truncated variables (RIFR and RDEFR on Tobit estimation) or for dummy variables (IFR and DEFR on logit estimations). Thus, the way the problem is addressed is by conducting a multinomial logit (Greene, 1993,

\footnotetext{
${ }^{7}$ Although dependent variables are clearly truncated, for completeness, regression estimations have been conducted controlling for fixed effects (available upon request). The results found are qualitatively the same as those obtained from Tobit estimations. This is not surprising as Hausman Test on regressions of RDEF reveals the non-existence of the endogeneity problem for the unobservable heterogeneity. See footnote 11

${ }^{8}$ This technique has been employed to tackle the potential endogeneity problem between variations of a firm's labour ratio and workers' productivity. Dependent variables have been advanced by one period.
} 
p. 666) for the joint distribution of four dummy variables; those that characterize significant changes in the length of labour contracts (ILR, DELR) and those of financial contracts (IFR, DEFR). Variable $\mathrm{V}$ encompasses all the events resulting from the combination of the previous variables. By working with the joint distribution of labour and financial variables, one can overcome the problem of endogeneity that emerges from univariate specifications that assume labour variables depend on financial variables. When the probabilities of events with labour and financial content are computed, we can derive marginal probabilities that move from financial to labour structure. One considers as control variables in the multinomial estimation those used in the previous univariate estimations. Specifically, variable V is defined in the following table:

\begin{tabular}{lllll}
\hline Variable & & & & \\
\hline Definition & ILR & DELR & IFR & DEFR \\
V $=8$ & 1 & 0 & 1 & 0 \\
$\mathrm{~V}=7$ & 1 & 0 & 0 & 1 \\
$\mathrm{~V}=6$ & 1 & 0 & 0 & 0 \\
$\mathrm{~V}=5$ & 0 & 1 & 0 & 1 \\
$\mathrm{~V}=4$ & 0 & 1 & 1 & 0 \\
$\mathrm{~V}=3$ & 0 & 1 & 0 & 0 \\
$\mathrm{~V}=2$ & 0 & 0 & 1 & 0 \\
$\mathrm{~V}=1$ & 0 & 0 & 0 & 1 \\
$\mathrm{~V}=0$ & 0 & 0 & 0 & 0 \\
\hline
\end{tabular}

Thus, one focuses on a specification like the following (Maddala, 1983, pp. 35):

$$
\begin{aligned}
T_{j}(V)_{i t}= & \alpha_{1 j} \text { DIFINCOST }_{i t}+\alpha_{2 j} \text { LTBANKDEBT }_{i t} \\
& +\alpha_{3 j} \text { LEVERAGE }_{i t} \\
& +\alpha_{4 j} \text { PRODUCTIVITY }_{i t}+\alpha_{5 j} \text { RD }_{i t} \\
& +\alpha_{6 j} \text { SMALL }_{i t}+\alpha_{7 j} \text { DIVERSIFIC }_{i t} \\
& +\eta_{i}^{\prime \prime}+\varepsilon_{i t}^{\prime \prime}
\end{aligned}
$$

With $T_{j}(V)=\log \left(\operatorname{prob}(V=j) / 1-\sum_{j=1}^{8} \operatorname{prob}(V=j)\right)$ $\eta_{i}^{\prime \prime}$ accounts for the unobservable heterogeneity, and $\varepsilon_{i}^{\prime \prime}$ is a white-noise error term.

Interestingly, with this specification one allows for a more flexible structure than that of the conditional logit estimations presented above. With variable V, one implicitly adopts the vision of a manager in a firm that has changed its financial structure and has to decide whether to hire long-term or short-term workers. Moreover, the manager also negotiates the length of financial contracts with lenders, and takes into consideration the effect that this length produces in the labour contracting (endogenous relationship). Thus, to investigate whether the combinations (ILR $=1$, IFR $=1)$ as well as $($ DELR $=1$, $\mathrm{DEFR}=1$ ) are more likely than alternatives in a multiple choice setting, one should contemplate all possible combinations of LR and FR. This is what variable $\mathrm{V}$ does.

As a result of the previous specification, one can compute the probability of different results for $\mathrm{V}(\mathrm{Pi}=$ $\operatorname{PROB}(\mathrm{V}=\mathrm{i})$ are denoted). This $\mathrm{Pi}$ allows one to compute conditional probabilities of changes in labour contract length contingent on changes in financial contract length. In particular, Prob(ILR = $1 / \mathrm{IFR}=1)=\mathrm{P} 8 /(\mathrm{P} 2+\mathrm{P} 4+\mathrm{P} 8) ; \quad \operatorname{Prob}(\mathrm{ILR}=1 /$ $\mathrm{DEFR}=1)=\mathrm{P} 7 /(\mathrm{P} 1+\mathrm{P} 5+\mathrm{P} 7)$ and $\operatorname{Prob}(\mathrm{ILR}=1 /$ $(\mathrm{IFR}=0 \quad$ AND $\quad$ DEFR $=0)=\mathrm{P} 6 /(\mathrm{P} 0+\mathrm{P} 3+\mathrm{P} 6)$. Concerning decreases in the financing ratio the expressions are $\operatorname{Prob}(\mathrm{DELR}=1 / \mathrm{DEFR}=1)=$ $\mathrm{P} 5 /(\mathrm{P} 1+\mathrm{P} 5+\mathrm{P} 7) ; \quad \operatorname{Prob}(\mathrm{DELR}=1 / \mathrm{IFR}=1)=$ $\mathrm{P} 4 /(\mathrm{P} 2+\mathrm{P} 4+\mathrm{P} 8) ; \quad \operatorname{Prob}(\mathrm{DELR}=1 /(\mathrm{IFR}=0$ AND DEFR $=0)=\mathrm{P} 3 /(\mathrm{P} 0+\mathrm{P} 3+\mathrm{P} 6)$. Finally, by conducting a $t$-test over pairs of the previous probabilities, one can test how important is the effect of changes in the length of financial contracts on the length of labour contracts.

It is worth emphasizing that by proceeding in that way, conditional probabilities are computed making use of the joint distribution of changes in financial as well as labour contract length. This is a natural way to incorporate in the estimations the existence of an endogenous relationship between both contract lengths.

\section{Data and Results}

\section{The data}

To test empirically the theoretical contentions, the database Survey on Business Strategies (Encuesta Sobre Estrategias Empresariales, ESEEE) is going to be used for the period 1991 to 2000. This database is updated annually by the Ministry of Science and Technology, and it contains information of approximately 3431 firms within 18 manufacturing sectors. This is an incomplete panel data of 28029 observations and it is sensibly representative of the distribution of firms by employment and size. Table 2 shows the evolution in the 1990s of the temporal labour ratio (LR) as well as the financing ratio (FR) defined as the ratio of short-term debt to total debt.

The data shows that the temporal labour ratio was around $20 \%$ during the 1990 s. $^{9}$ Not surprisingly,

\footnotetext{
${ }^{9}$ One should say that these figures are higher than the figures shown in studies like Hernando and Tribó (2003), because the database used is more balanced in terms of size of firms because it includes a higher proportion of small firms. Smaller firms imply, according to Table 2, a higher temporal labour ratio.
} 
Table 2. Temporal labour ratio and financing ratio

\begin{tabular}{llll}
\hline & $\begin{array}{l}\text { Mean LR } \\
(\%)\end{array}$ & $\begin{array}{l}\text { \% of firms with } \\
\text { LR }>0(\%)\end{array}$ & $\begin{array}{l}\text { Mean } \\
\text { FR }^{\mathrm{b}}(\%)\end{array}$ \\
\hline 1991 & 23.73 & 79.12 & 70.37 \\
1992 & 22.76 & 77.74 & 65.79 \\
1993 & 22.68 & 80.21 & 58.61 \\
1994 & 22.95 & 81.54 & 59.54 \\
1995 & 21.53 & 82.51 & 53.96 \\
1996 & 22.24 & 82.14 & 51.50 \\
1997 & 21.89 & 82.06 & 50.23 \\
1998 & 19.98 & 81.51 & 45.67 \\
1999 & 19.42 & 81.12 & 42.41 \\
2000 & 19.13 & 80.40 & 42.87 \\
$1991-2000$ & 21.67 & 80.79 & 53.08 \\
\hline
\end{tabular}

${ }^{\mathrm{a}}$ This is defined as the ratio of temporal workers to the total number of firms' employees.

${ }^{\mathrm{b}}$ This is defined as the ratio of short-term debt to total debt.

this ratio has shown a steady decrease since the 1997 Spanish labour reforms, to stimulate long-term labour contracting, came into effect.

Table 2 also shows that firms' debt financing ratios have been decreasing continually since 1991, and especially after 1997. Thus, one may expect the existence of a link between the length of both types of contracts, labour and financial. This is the main theme of this article.

Finally, it is worth noting that in those years of recession (1992), the labour ratio decreases significantly. This can be explained because firms fire their short-term workers during these periods.

\section{Contingency analysis}

As preliminary evidence, an analysis of the probability to change the labour ratio is presented significantly for those firms that had changed remarkably their financing ratio. We also look at the control variables from the basic specification (1).

Table 3 shows that those firms that have issued short-term debt higher than the median for the sector in a given year; hire more short-term and long-term worker than the median for the sector that year. The same is true for those other firms that have changed significantly their financing structure by issuing more long-term debt. Thus, at this level of analysis, one can only appreciate some connection between changes in firms' financing structure and their labour structure, but there is no direct relation between changes in the length of these contracts. In addition, leverage, in general, does stimulate the use of long-term as well as short-term labour contracts; this is not fully consistent with Hanka's (1998) result.

Non-financial factors also have an impact on labour policy. First, labour productivity is related to the presence of long-term workers. Second, firms' R\&D efforts seem to be accompanied with the hiring of more longterm workers and/or short-term ones. In general, this kind of investment is more productive when workers have long-term contracts because in that case they are more willing to invest in specific human capital as has been argued previously. This is what will be found in the following univariate analysis. However, one can justify that R\&D-intensive firms are generally smallgrowth firms with a clear preference for flexibility. This is linked to short-term labour contracts. Finally, bigger firms adopt two alternative labour policies: they hire a significant amount of long-term workers or of short-term workers. However, the univariate analysis that follows this result changes substantially as only small firms show a significant effect. They hire short-term workers. This latter result is going to be interpreted as a mechanism to be hedged against demand or supply shocks.

\section{Univariate estimations}

As has been explained in the methodology section, two types of estimations have been conducted. First, one relies on conditional logit estimations over specification (1) in order to eliminate potential endogeneity problems with the unobservable heterogeneity. Thereafter, Tobit estimations are conducted to enrich the results by using continuous, although truncated, dependent variables. Table 1 shows the results. In the logit estimations DELR (row 1) and ILR (row 4) are the dependent variable, while in the Tobit estimations RDELR (rows 2,3) and RILR (rows 5,6) are the variables to be explained. Some estimations have introduced variables D97RIFR and D97RDEFR (rows 3,6) to check the relevance of the 1997 labour reforms. D97RIFR is constructed as the product of RIFR times a dummy variable (D97) that is equal to one if the year is 1997 onwards, and zero otherwise. However, D97RDEFR is the product of RDEFR times D97.

Table 1 shows that a big increase in long-term debt gives firms incentives to hire significantly more workers with a long-length contract. ${ }^{10}$ Moreover, when

\footnotetext{
${ }^{10}$ This is true in the Tobit estimations but not strictly in the logit ones. In these latter estimations increases in the length of a firm's financial structure generate incentives to hire significantly more workers with any contract length. However, in the next section, it will be seen that when controlling for additional endogeneity problems, increases in long-term debt have a superior impact on increases in the length of labour contracts compared with the impact generated by increases in short-term debt.
} 
firms increase their short-term debt, there is a significant increase in short-term labour contracts. This result is along the lines of what has been suggested in the theoretical section. ${ }^{11}$ Note that this result is rather predictable. If financial flexibility is high enough (linked to long-term debt), firms can afford to hire workers with a long-term contract. However, when there is less financial slack (due to short-term debt) only short-term labour contracts are available. Thus, a firm's decision to invest in human resources is closely linked to the variations in its financial structure. This confirms the basic claim. A minor point is that Hanka's (1998) result about the existence of a positive relationship between leverage and the hiring of short-term workers may not be true when a firm issues long-term debt. Moreover, the estimation reflects that a firm's overall leverage is not related to significant variations in a firm's temporal labour ratio. The variation in the time schedule of a firm's leverage really affects the variations in the length the labour contract.

Another result that links a firm's financial structure with its labour policy and provides interesting new insights is that an increase in the financing cost (DIFINCOST) generates lower incentives for a firm to hire long-term workers. This may be interpreted in different ways. First, long-term workers are more costly to hire and a firm with higher financing costs cannot afford those kinds of workers. A second interpretation of this result relies on the inverse relation of this variable with a project's quality. The lower the quality, the higher a firms financing costs. It has been found consistent with the theoretical contentions, that developing low-quality projects leads firms to hire fewer long-term workers. Third, DIFINCOSTS may be interpreted inversely as a proxy like LTBANKDEBT of the financier's commitment to the firm. This eventually allows the development of long-term projects. Both variables signal that increases in that commitment stimulate firms to hire permanent workers. This is consistent with our theory. Finally, one can connect the DIFINCOSTS variable with the degree of overall uncertainty and risks. The higher the uncertainty and/or the risk, the higher are a firm's financing costs. Thus, one can interpret the result found in terms of a reduction in labour contract length in periods of high uncertainty. ${ }^{12}$

Interestingly, the aforementioned relationship of a firms financing costs and its labour ratio suggests the existence of a counter cycle financing effect on the length of a firm's labour contracts. By lowering interest rates at the trough of a recession, the Monetary Authority decreases the firm's financing costs. This generates, according to the results, an increase in the firm's labour contract length in times of recession. ${ }^{13}$ The reverse is true at the onset of an expansion.

Table 1 also shows (conditional logit estimations) that small firms employ more workers with shortlength contracts than big firms. ${ }^{14}$ Small firms in some sectors are the marginal producers. This makes them quite sensible to demand shocks. By using short-term contracts to hire workers, they get some flexibility to deal efficiently with demand variability. Along this line, Funke et al. (1998), shows the relevance of a firm's size effect in explaining the link between financial contracts with labour contracts. They find that in a small firm, financing constraints are more relevant than they are in a big firm. This, in turn, affects a firm's labour policy.

A firm's productivity generates results in either direction. On the one hand, one finds, consistent with our theoretical contentions that the more productive firms prefer to hire long-term workers. ${ }^{15}$ On the other hand, another type of productive firm is more interested in the short-term labour contracts. Along this line, Cuñat (1999) proves, making use of another Spanish database, that growth firms

\footnotetext{
${ }^{11}$ When one estimates RDELR with a fixed-effect regression (available upon request), one also finds a positive and significant coefficient of RDEFR $\left(0.019^{* * *}\right)$, but not for RIFR. Similarly, in the estimation of RILR, the coefficients of RIFR (0.036***) and of RDEFR $\left(0.023^{* * *}\right)$ are both significant and positive. Hausman tests also reveal the non-existence of fixed-effects on RDEFR estimation. That is why we rely on Tobit estimations as dependent variables RDEFR and RIFR are totally truncated.

${ }^{12}$ There is also another indirect interpretation. Those firms that have been able to reduce their financing costs (good firms) are potential subjects of a takeover. Thus, they can hire long-term workers as a 'poison pill' to avoid to be taken over (Pagano and Volpin, 2002).

${ }^{13}$ Note that it has been found in the descriptive analysis that in the recessive year of 1992, there was a significant decrease in the temporal labour ratio. This is in accordance with our theory.

${ }^{14}$ This result also works when different variables like the log of sales are used.

${ }^{15}$ There is a relationship between a firm's productivity with union power. The greater the negotiated power of the unions, the lower firm's productivity. They are also less likely to negotiate long-term contracts; preferring short-term labour contracts as a way to 'hold up' workers with continuous negotiations. This allows the unions to maintain their bargaining power (Murphy, 1992). Thus, a direct connection is found between a firm's productivity and a bias towards long-term labour contracting.
} 
(in principle, more productive) prefer short-term debt. This is to avoid the underinvestment inefficiency of the debt overhang problem. The central hypothesis allows one to connect this feature with an increase in the temporal labour ratio. This may explain the latter result.

It is worth emphasizing the effect of RD as a stimulus to contract workers with a long-term contract. This is justified because R\&D investments are complementary to other types of investments like human capital. This stimulates permanent workers to acquire specific human capital. A second reason for this result is that $\mathrm{R} \& \mathrm{D}$-intensive projects tend to be long-term. ${ }^{16}$

A final comment refers to the effect of the 1997 labour reform. In that year, there were reductions in payroll taxes ranging from 40 to $90 \%$ as well as in dismissal costs for unfair dismissals by about $40 \%$, for those firms that hired workers from some special groups ${ }^{17}$ with long-term contracts. To study the effect of that reform, rows three and six show the results of Tobit estimations that incorporate variables D97RDEFR and D97RIFR. Interestingly, it can be observed that after 1997, the financing effect on longlength labour contracting is much more severe. In particular, before 1997 those significant increases in the long-term (short-term) debt had no effect (negative effect) on the significant hiring of workers with long-term contracts. However, after 1997 the effect in both cases is positive, especially for long-term debt variations.

\section{Endogeneity problems}

The methodology section has explained that there is a recognizable endogenous relationship between variations in the length of labour contracts and those in the length of financial contracts. This may bias the coefficients of the estimations. To overcome this problem and check the robustness of the main results of the paper, all the possible labour and financing scenarios are integrated in a unique dependent variable, V. Then, a multinomial logit is estimated of that variable, $\mathrm{V}$, for the specification that incorporates all control variables used in the previous univariate estimations. Results are shown in Table 4.
Table 4 shows that a significant decrease in a firm's labour ratio is more likely when there is a decrease in the financing ratio $(20.61 \%)$ as opposed to those situations where there is no variation $(13.58 \%)$ or there is an increase in that ratio $(17.51 \%)$. In addition, all these differences are significant among them. Moreover, there is a significant higher probability that a firm hires short-term workers when it issues short-term debt $(30.42 \%)$ than when it does not make any debt issues $(23.10 \%)$ or issues longterm debt $(29.50 \%)$. Thus, the positive relationship between variations in the length of both types of contracts, financial and labour, is fully confirmed once one controls for endogeneity problems. This is the main idea developed in the article.

\section{Conclusions}

This study has analysed the relationship between variations in the length of labour contracts and of financial contracts. Both contracts are channels through which firms obtain financial or human capital which are two basic resources of the firm. To exploit the complementarities of such resources better, contracts should share common characteristics. The conjecture is that significant variations in the length of financial contracts, because of raising capital, are in direct relation with variations in the length of labour contracts because of hiring new workers. This statement is based on the commitment effect linked to long-term financing that reinforces the incentives of workers with long-term contracts to make specific investments. Additional value is created with these human capital investments, which makes payment to debt holders more likely. This gives debt holders incentives to offer long-term debt contracts and, as a result, gives the entrepreneur incentives to hire workers with long-term contracts. Thus, it seems that a natural complementarity between changes in the length of financial contracts and in the length of labour contracts may exist. This recognizes the existence of financing effects in any study of the optimal length of labour contracts as a way to enrich the traditional trade-off analysis between negotiation

\footnotetext{
${ }^{16}$ It may be argued that the connection between financial and labour contract length is spurious in a sense that an increase in a firm's growth expectations would make long-term financial and labour contracts more attractive. By incorporating the R\&D variable as a proxy of a firm's growth expectations, the robustness of the main result in the paper has been proved. However, an additional component potentially correlated with independent variables may exist in the error term. To treat this issue, one needs to address endogeneiry issues more systematically. This is made in the following section.

${ }^{17}$ Workers under 30 years of age, workers over 45 years of age, the long-term unemployed, women under-represented in their occupations and disabled workers.
} 


\begin{tabular}{|c|c|c|c|c|}
\hline & \multicolumn{4}{|l|}{ Frequency $^{\mathrm{a}}$} \\
\hline & $\mathrm{ILR}=1$ & $\mathrm{ILR}=0$ & $\mathrm{DELR}=1$ & DELR $=0$ \\
\hline $\mathrm{IFR}=1(n=1493)$ & 28.90 & 71.10 & 16.45 & 84.55 \\
\hline $\mathrm{IFR}=0(n=14802)$ & 23.49 & 76.51 & 13.77 & 86.23 \\
\hline Pearson $^{\mathrm{b}}$ & $46.41(0)$ & & $17.17(0)$ & \\
\hline $\mathrm{DEFR}=1(n=324)$ & 27.76 & 72.24 & 17.81 & 82.19 \\
\hline $\mathrm{DEFR}=0(n=15971)$ & 24.19 & 75.81 & 13.58 & 86.42 \\
\hline Pearson $^{\mathrm{b}}$ & $17.44(0)$ & & $37.00(0)$ & \\
\hline DIFINCOST $>$ median $^{c}$ & 25.27 & 74.73 & 15.77 & 84.23 \\
\hline DIFINCOST $<=$ median $^{\mathrm{c}}$ & 26.28 & 73.72 & 15.97 & 84.03 \\
\hline Pearson $^{\mathrm{b}}$ & $1.209(0.271)$ & & $0.07(0.791)$ & \\
\hline LTBANKDEBT $>$ median $^{c}$ & 25.30 & 74.70 & 16.51 & 83.49 \\
\hline 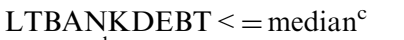 & 25.67 & 74.33 & 13.78 & 76.22 \\
\hline Pearson $^{b}$ & $0.219(0.640)$ & & $17.261(0)$ & \\
\hline 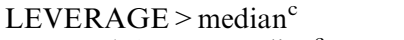 & 25.74 & 74.26 & 15.36 & 84.64 \\
\hline LEVERAGE $<=$ median $^{\mathrm{c}}$ & 24.44 & 75.56 & 14.10 & 85.90 \\
\hline Pearson ${ }^{\mathrm{b}}$ & $3.268(0.072)$ & & $4.592(0.032)$ & \\
\hline PRODUCTIVITY $>$ median $^{c}$ & 24.80 & 75.20 & 14.87 & 85.13 \\
\hline PRODUCTIVITY $<=$ median $^{\mathrm{c}}$ & 24.82 & 75.18 & 14.00 & 86.00 \\
\hline Pearson $^{b}$ & $0.008(0.978)$ & & $2.337(0.126)$ & \\
\hline $\mathrm{RD}>$ median $^{\mathrm{c}}$ & 27.99 & 72.01 & 15.86 & 84.14 \\
\hline $\mathrm{RD}<=$ median $^{\mathrm{c}}$ & 23.19 & 76.81 & 13.64 & 86.36 \\
\hline Pearson ${ }^{\mathrm{b}}$ & $41.444(0)$ & & $13.516(0)$ & \\
\hline SMALL = 1 & 22.20 & 77.80 & 13.82 & 86.18 \\
\hline SMALL $=0$ & 27.47 & 72.53 & 15.07 & 84.93 \\
\hline Pearson ${ }^{b}$ & $56.862(0)$ & & $4.831(0.028)$ & \\
\hline DIVERSIFIC. $>$ median $^{\mathrm{c}}$ & 24.12 & 75.88 & 14.65 & 75.35 \\
\hline DIVERSIFIC. $<=$ median $^{c}$ & 25.39 & 74.61 & 14.23 & 75.77 \\
\hline Pearson ${ }^{b}$ & $3.309(0)$ & & $0.553(0.457)$ & \\
\hline
\end{tabular}

${ }^{\mathrm{a}}$ Frequency expressed in percentages. Variables defined in the text.

${ }^{\mathrm{b}}$ Test of Pearson $\left(\chi^{2}\right)$. The null hypothesis is that both variables are statistically independents.

${ }^{\mathrm{c}}$ Median values for the corresponding sector and year.

Table 4. Conditional probabilities

\begin{tabular}{|c|c|c|}
\hline & $\begin{array}{l}\text { Probability } \\
(\mathrm{ILR}=1) \\
\text { conditioned to }\end{array}$ & $\begin{array}{l}\text { Probability }{ }^{\mathrm{b}} \\
(\mathrm{DELR}=1) \\
\text { conditioned to }\end{array}$ \\
\hline $\mathrm{IFR}=1$ & 30.42 & 17.51 \\
\hline $\mathrm{IFR}=0$ and $\mathrm{DEFR}=0$ & 23.10 & 13.58 \\
\hline$P$-value ${ }^{\mathrm{b}}$ & $187.60(0)$ & $82.52(0)$ \\
\hline $\mathrm{DEFR}=1$ & 29.50 & 20.61 \\
\hline $\mathrm{DEFR}=0$ and $\mathrm{IFR}=0$ & 23.10 & 13.58 \\
\hline$P$-value ${ }^{\mathrm{b}}$ & $109.81(0)$ & $158.20(0)$ \\
\hline $\mathrm{IFR}=1$ & 30.42 & 17.51 \\
\hline $\mathrm{DEFR}=1$ & 29.50 & 20.61 \\
\hline$P$-value ${ }^{\mathrm{b}}$ & $15.40(0)$ & $68.22(0)$ \\
\hline
\end{tabular}

${ }^{a}$ In percentage $\%$. See the definition of the variables in the text.

${ }^{\mathrm{b}} t$-test of significant differences in the probabilities.

costs and uncertainty. This is the main contribution of this study.

The empirical analysis uses a data set of Spanish manufacturing firms for the period 1991-2000. The results support the theoretical contention. Those firms that have increased (decreased) significantly their short-term financing ratio by raising capital are more likely to increase (decrease) significantly their temporal labour ratio by hiring new workers. In addition, it is found that an increase in a firm's financing costs, which is a proxy for its deteriorating quality, and/or low financier's commitment to the firm, as well as the overall uncertainty, is inversely related to the hiring of long-term workers. Finally, other factors have been found that shape the length of labour contracts. First, labour productivity may induce significant changes in the length of labour contracts in both directions. Second, R\&D investments induce a firm to hire workers with long-term contracts to seek complementarities with human capital investments that are more likely in long-term workers. Third, it has been proved that the 1997 Spanish labour reform promoted long-term labour contracting highlighting the relevance of the changes in the length of financial contracts in either direction as a way of giving firms incentives to hire permanent workers. 
One of the outcomes of this article is to emphasize the existence of a natural financing mechanism that induces counter cycle movements in the labour contract length. By lowering interest rates at the trough of a recession, the Monetary Authority decreases the firm's financing costs. This should generate, according to the results, an increase in the firm's labour contract length in times of recessions. The reverse is true at the onset of an expansion.

Finally, a natural extension is described. This is to examine other relationships between the characteristics of financial contracts and those of labour contracts. In particular, it is thought that the type of retribution (fix versus variable) in labour contracts is well connected with the characteristics of the "fixvariable' nature of financial contracts (debt versus equity). To test this and other ideas will be the subject of future research.

\section{Acknowledgements}

I deeply appreciate the comments of Ignacio Hernando from the Bank of Spain as well as those of participants in the EALE conference, Paris (2002). All errors are my own responsibility.

\section{References}

Ayala, L., Martínez, R. and Ruiz-Huerta, J. (2002) Institutional determinants of the unemploymentearnings inequality trade-off, Applied Economics, 34, 179-95.

Bárcena, J. C. and Campo, M. L. (2000) Short-term or long-term labor contracts, Labour Economics, 7, 249-60.

Barney, J. B. (1991) Firm resources and sustained competitive advantage, Journal of Management, 17, 99-120.

Becker, G. S. (1964) Human Capital: A Theoretical and Empirical Analysis, Columbia University Press, New York.

Chamberlain, G. (1980) Analysis of of covariance with qualitative data, Review of Economic Studies, 45, 225-38.

Cuñat, V. (1999) Determinantes del plazo de endeudamiento de las empresas españolas, Investigaciones Económicas, 23, 351-92.

Del Brio, E., De Miguel, A. and Pindado, J. (2003) Investment and firm value: an analysis using panel data, Applied Financial Economics, 13, 893-903.

Dye, R. (1985) Optimal length of contracts, International Economic Review, 26, 251-70.

Funke, M., Maurer, W., Siddiqui, S. and Strulik, H. (1998) The employment-financing nexus: evidence from a panel of West German firms, Small Business Economics, 11, 225-35.
Garvey, T. and Swan, P. (1992) The interaction between financial and employment contracts: a formal model of Japanese corporate governance, Journal of the Japanese and International Economies, 6, 247-74.

Gray, J. A. (1978) On indexation and contract length, Journal of Political Economy, 86, 1-18.

Greene, W. H. (1993) Econometric Analysis, Macmillan Publishing Company, New York.

Hanka, G. (1998) Debt and the terms of employment, Journal of Financial Economics, 48, 245-82.

Hendricks, W. E. and Kahn, L. M. (1983) Cost of living clauses in union contracts: determinants and effects, Industrial and Labor Relations Review, 36, 447-60.

Hernando, I. and Tribó, J. (2003) Contratos laborales y financieros. Un estudio para las empresas españolas, Revista de Economía Aplicada, 11, 33-49.

Llorca Vivero, R. (2002) The impact of process innovations on firm's productivity growth: the case of Spain, Applied Economics, 34, 1007-16.

Maddala, G. S. (1983) Limited Dependent and Qualitative Variables in Econometrics, Cambridge University Press, Cambridge.

Martin, R. (2003) Debt financing and entry, International Journal of Industrial Organization, 21, 533-49.

Murphy, K. J. (1992) Determinants of contract duration in collective bargaining agreements, Industrial and Labor Relations Review, 45, 352-65.

Murphy, K. J. (2000) What effect does uncertainty have on the length of labor contracts?, Labour Economics, 7, 181-201.

Osano, H. (1997) An evolutionary model of corporate governance and employment contracts, Journal of the Japanese and International Economies, 11, 403-36.

Pagano, M. and Volpin, P. (2002) Managers, workers and corporate control, ECGI Finance Working Paper $01 / 2002$.

Ragan, C. (1995) A risk-sharing view of real wages and contract length, Canadian Journal of Economics, 28, 1161-79.

Rendón, S. (2000) Job creation under liquidity constraints: the Spanish case, Working Paper 488, Universitat Pompeu Fabra.

Sánchez, R. and Toharia, L. (2000) Temporary workers and productivity: the case of Spain, Applied Economics, 32, 583-91.

Sharpe, S. (1990) Asymmetric information, bank lending and implicit contracts: a stylized model of customer relationships, Journal of Finance, 45, 1069-87.

Sharpe, S. A. (1994) Financial market imperfections, firm leverage and the cyclicality of employment, American Economic Review, 84, 1060-74.

Topel, R. (1986) Job mobility and earnings growth: a reinterpretation of human capital earnings functions, in Research in Labor Economics (Ed.) R. G. Ehrenberg, JAI Press, pp. 199-233.

Tsoulouhas, T. (1999) Renegotiation-proof labour and credit contracts with worker mobility, Economica, 66, 434-54.

Wernerfelt, B. (1984) A resource-based view of the firm, Strategic Management Journal, 5, 171-80. 